\title{
IMPORTANGE OF WEED CONTROL PRIOR TO PLANTING FOR THE ESTABLISHMENT OF PLANTED FORESTS IN SABAH, MALAYSIA
}

\author{
Alwi $\mathrm{A}^{1}$, Lapammu $\mathrm{M}^{1}$, Jarapudin $\mathrm{Y}^{1,2}$, Molony $\mathrm{K}^{3}$, Boden $\mathrm{D}^{4}$, Macdonell $\mathrm{P}^{5}$, Warburton $\mathrm{P}^{6}$, Brawner $\mathrm{J}^{2,7}$ \\ \& Meder $\mathbf{R}^{2,8, *}$ \\ ${ }^{1}$ Sabah Softwoods Bhd, PO Box 60966, 91019 Tawau, Sabah, Malaysia \\ ${ }^{2}$ Forest Industries Research Centre, University of the Sunshine Coast, Sippy Downs QLD 4556, Australia \\ ${ }^{3}$ Sinamatella Ltd, 9 Carling Road, Whakatane 3120, New Zealand \\ ${ }^{4}$ Boden EF Associates, PO Box 162, Cooroy, QLD 4563, Australia \\ ${ }^{5}$ Forestry Research Services Pty Ltd, 35 Gyndier Drive, Tinbeerwah, QLD 4563, Australia \\ ${ }^{6}$ Nur-Seed Pty Ltd, Church St, Pomona, QLD 4568, Australia \\ ${ }^{7}$ University of Florida, Department of Plant Pathology, Gainesville, FL 32611, USA \\ ${ }^{8}$ Meder Consulting, PO Box 3185, Bracken Ridge, QLD 4017, Australia \\ *roger@mederconsulting.com
}

Submitted October 2019; accepted March 2020

\begin{abstract}
The establishment of fast-growing trees in the production forests of Sabah, Malaysia may be severely compromised if weed control, during the initial months following site preparation, is inadequate. A twoway factorial experimental design, comparing levels of manual and chemical weed control, with and without fertilisation at planting, was used to demonstrate significant impacts on the mean tree volume of Acacia mangium trees, 31/2 years after plantation establishment. Eliminating weeds at 23 months, with remedial treatment across the factorial experiment, demonstrated little residual effects. No productivity benefit was observed at 14 months, after remedial weed control at 23 months post-establishment, nor was there any productivity gain observed at 10 months, after remediation application of fertiliser at 26 months post-establishment. The results emphasised the need for weed control during site preparation, including complete chemical weed control prior to planting and quarterly until canopy closure.
\end{abstract}

Keywords: Fertiliser, weed control, Acacia mangium, plantation forest, site preparation

\section{INTRODUCTION}

Weeds within a planted forest compete for space, nutrients and water (Sands and Nambiar 1984, Keenan et al. 2004). Manual slashing is commonly used to manage woody weeds in previously logged over forest areas in Sabah, Malaysia. However, with each succeeding rotation there is an increasing build-up of aggressive weeds such as Mikania, Paspalum and Chromolena spp. These aggressive, competing weeds can only be controlled by chemical herbicides, since slashing is inefficient in eliminating them. Quantifying the impact of inadequate weed control at establishment, on the subsequent growth rates of tropical plantation forests, helps to prioritise best management practices required for the development of planted forests.

A considerable amount of research has examined the effect of weed control on radiata pine establishment in Australia and New Zealand (Nambiar and Zed 1980, Balneaves and Christie 1988, Messina 1990, Wilkinson and Neilson 1990, Richardson 1993). Baker et al. (1988) showed that the use of mixed hexazione, amitrole and atrazine formulation increased tree volume by $120 \%$ compared to control, when weed cover was reduced from $80 \%$ to $10 \%$. Competition from weeds affects crown volume more than height (Florence 1996, Schumann 1989). A gain of $275 \%$ in height, compared to control, was achieved in eucalypt seedlings at 11 months after application of herbicide weed control at establishment (Schumann 1989). Downes et al. (2014) examined the effects of fertiliser and stocking on the wood quality of ten-year-old Eucalyptus globulus grown in Western Australia. Application of nitrogen fertiliser $\left(250 \mathrm{~kg} \mathrm{ha}^{-1}\right)$ at 
age two years resulted in average $\mathrm{DBH}$ of $22.3 \mathrm{~cm}$ (overbark) compared to $20.4 \mathrm{~cm}$ in unfertilised controls. Although differences were observed in wood properties (MOE, density, Kraft pulp yield), they were not considered significant.

A demonstration trial, to compare the control of weeds by chemical spraying before planting until canopy closure, was established inside a commercial production forestry plantation in south-west Sabah state in BorneoMalaysia. The objectives of the demonstration trials were to illustrate the growth advantages of chemical weed control at early establishment or later, and to further quantify the response of fertiliser application following canopy closure in A. mangium.

\section{MATERIALS AND METHODS}

A bifactorial weed control and fertiliser trial was established at Matamas Estate (Block 134G), Sabah Softwoods Bhd., approximately $70 \mathrm{~km}$ west of Tawau, Sabah, Borneo-Malaysia (N 04 ${ }^{\circ}$ 41'13.1" E $117^{\circ} 44^{\prime} 34.4$ ", elevation $213 \mathrm{~m}$ asl, rainfall $2315 \mathrm{~mm}^{-1}$ ). Four treatments were used as described in Table 1. Weed control was conducted before planting using either manual slashing (T1 and T2) or chemical control (T3 and T4) with glyphosate $\left(6 \mathrm{~L} \mathrm{ha}^{-1}\right)$ and metsulfuron methyl $\left(60 \mathrm{~g} \mathrm{ha}^{-1}\right)$. An initial application of fertiliser was applied [50 g triple super phosphate (TSP), $10 \mathrm{~g}$ elemental P] in $\mathrm{T} 2$ and T4. Acacia mangium seedlings were then planted in four replicates, in $5 \times 5$ tree plots (with the inner $3 \times 3$ trees assessed). Weed control using glyphosate was maintained at ca. 3-month intervals in T3 and T4 during the first nine months post-establishment, at which time canopy closure had been reached. At 23 months post-establishment, additional weed control in selected plots were conducted using glyphosate in treatments R1T2, R3T1, R3T2 and R4T1, while at 26 months a booster dose of fertiliser [N 100, P 50, K $50\left(\mathrm{~kg} \mathrm{ha}^{-1}\right)+$ trace micronutrients] was applied in treatments R2T4, R3T3, R3T4 and R4T3.

The growth and form were monitored at monthly intervals from 9 to 42 months. It was observed that the trial was suffering greatly from Ceratocystis disease resulting in increased mortality (Brawner et al. 2015). The trial was concluded at 42 months as the level of diseaseinduced mortality was outside the experimental design parameters. However the trial age and data collected was sufficient to make several key observations.

\section{RESULTS AND DISCUSSION}

Figure 1 shows the difference in weed control at Matamas trial at five months post-establishment, between T1 (manual slashing with no fertiliser) and T4 (chemical weed control with fertiliser application at planting). The difference in weed cover and seedling height were most obvious. Figure 2 presents the mean tree volume of the four treatments which clearly shows the benefit of chemical weed control prior to planting. The difference in mean tree volume at 42 months for T4 $\left(0.161 \mathrm{~m}^{3}\right)$ and T1 $\left(0.064 \mathrm{~m}^{3}\right)$ is $0.097 \mathrm{~m}^{3}$. This equates to a $167 \%$ increase in productivity between the two treatments or a difference in mean stand volume of $71.6 \mathrm{~m}^{3}$ per hectare at 42 months. This is consistent with observations across Australasian plantations of radiata pine (120\% increase in tree volume) or Eucalypt (275\% increase in tree height) (Baker et al. 1988, Schumann 1989). Similarly, productivity in fully-weeded plots of Eucalyptus tereticornis plantations in Kerala, India was found to be 1.69 to 2 times higher than that of non-weeded plots (Pillai 2012, Sankaran et al. 2013). There has

Table 1 Weed control and fertiliser treatments deployed at Matamas demonstration trial

\begin{tabular}{|c|c|c|c|}
\hline Treatment & Weed control & $\begin{array}{c}\text { Fertiliser at } \\
\text { establishment }\end{array}$ & $\begin{array}{l}\text { Fertiliser }\left(\mathrm{kg} \mathrm{ha}^{-1}\right) \\
\quad \text { at } 26 \text { months }\end{array}$ \\
\hline T1 (W0F0) & Manual slash & - & \\
\hline T2 (W0F1) & Manual slash & $50 \mathrm{~g}$ TSP $(10 \mathrm{~g} \mathrm{P})$ & \\
\hline T3 (W1F0) & $\begin{array}{l}\text { Glyphosate }\left(6 \mathrm{~L} \mathrm{ha}^{-1}\right) \\
\text { Metsulfuron }\left(60 \mathrm{~g} \mathrm{ha}^{-1}\right)\end{array}$ & - & $\begin{array}{l}\text { N } 100, \text { P } 50, \mathrm{~K} 50 \\
\mathrm{Cu}, \mathrm{Zn}, \mathrm{Fe}, \mathrm{Mn}, \mathrm{Mg}, \mathrm{B} \text { trace }\end{array}$ \\
\hline $\mathrm{T} 4(\mathrm{~W} 1 \mathrm{~F} 1)$ & $\begin{array}{l}\text { Glyphosate }\left(6 \mathrm{~L} \mathrm{ha}^{-1}\right) \\
\text { Metsulfuron }\left(60 \mathrm{~g} \mathrm{ha}^{-1}\right)\end{array}$ & $50 \mathrm{~g}$ TSP $(10 \mathrm{~g} \mathrm{P})$ & $\begin{array}{l}\text { N } 100, \text { P } 50, \text { K } 50 \\
\mathrm{Cu}, \mathrm{Zn}, \mathrm{Fe}, \mathrm{Mn}, \mathrm{Mg}, \mathrm{B} \text { trace }\end{array}$ \\
\hline
\end{tabular}




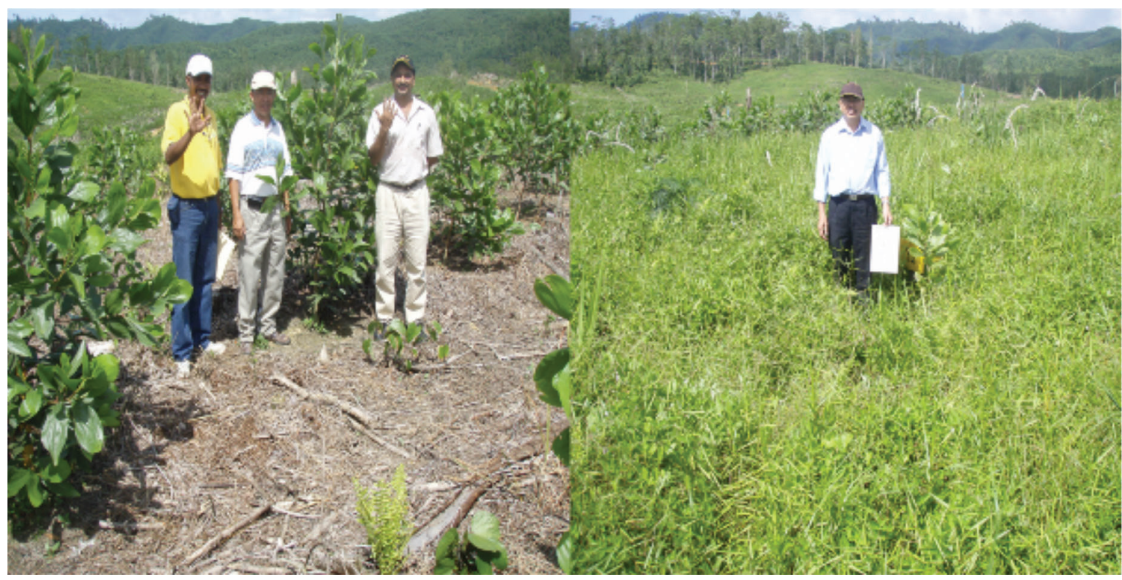

Figure 1 The Matamas weed control demonstration trial at 5 months, left $=\mathrm{T} 4(\mathrm{~W} 1 \mathrm{~F} 1)$, right $=\mathrm{T} 1(\mathrm{~W} 0 \mathrm{~F} 0)$

been a steady increase in the volume difference (per mean tree) between chemical weed control plus fertiliser (T4) and weed control by slashing (T1 and T2) from $105 \%$ at 9 months to $155 \%$ at 24 months, and $167 \%$ at 42 months. However, mortality caused by Ceratocystis did not allow for the trends to be examined until rotation age.

The results in Figure 2 highlight the fact that fertiliser application alone has absolutely no benefit in stand productivity (no difference is observed between W0F0 and W0F1). If fertiliser is to be applied, then the benefit of that will only be gained if effective weed control is also undertaken. In fact, it is more beneficial to undertake weed control alone than fertiliser application alone, as $\mathrm{W} 1 \mathrm{~F} 0$ shows $50 \%$ improved productivity over either W0F0 or W0F1.

Follow-up weed control at 23 months and additional application of fertiliser at 26 months did not show any significant growth response (Figure 3). This has considerable implications on silvicultural practices, implying that early and dramatic weed control is essential for good site establishment but attempts at remedial control are not worth the cost or effort, as there is little to be gained from mid-rotation remedial weed management. Similarly, inefficient weed control before planting can result in patches of remnant weeds, which, in addition to the soil seed bank, act as a seed and spore source for recolonisation of a weed spectrum during early growth of the seedlings. It is essential to ensure consistent weed control to provide the best opportunity for early tree growth following establishment. Remedial weed treatments were not effective in restoring losses in early productivity.

The economic cost of weed control has been modelled. The growth differences at 20 months,

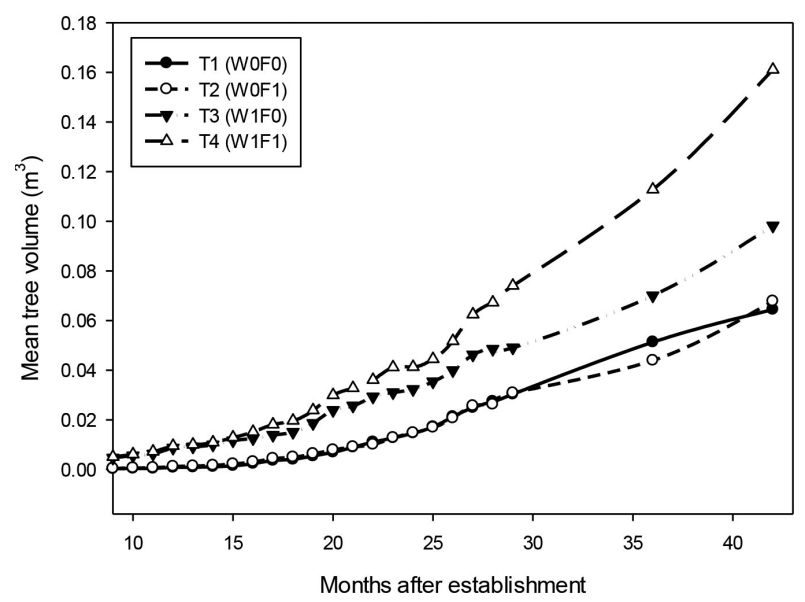

Figure 2 Mean tree volume over time for four treatments at the Matamas demonstration trial 

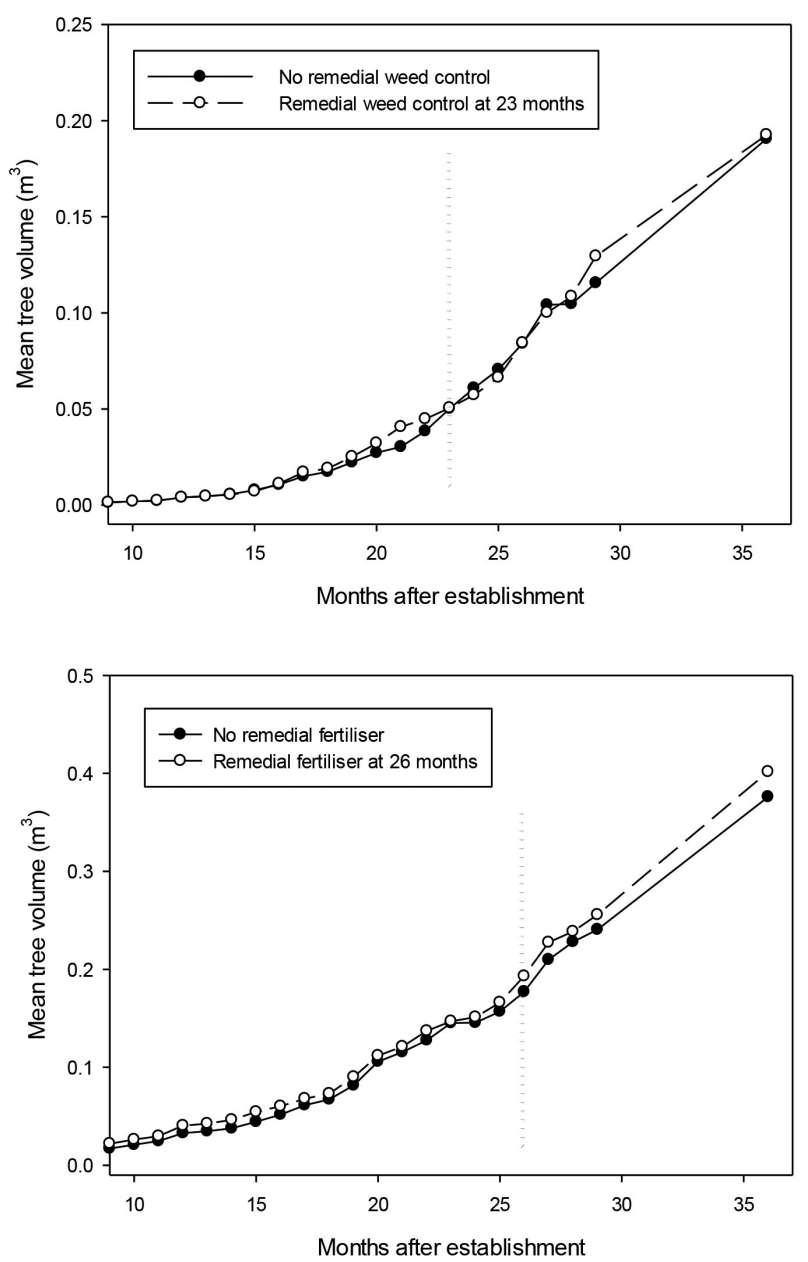

Figure 3 Mean tree volume over time: (top) remedial chemical weed control at 23 months, and (bottom) remedial fertiliser application at 26 months; the vertical dotted lines shows timing of remedial treatments

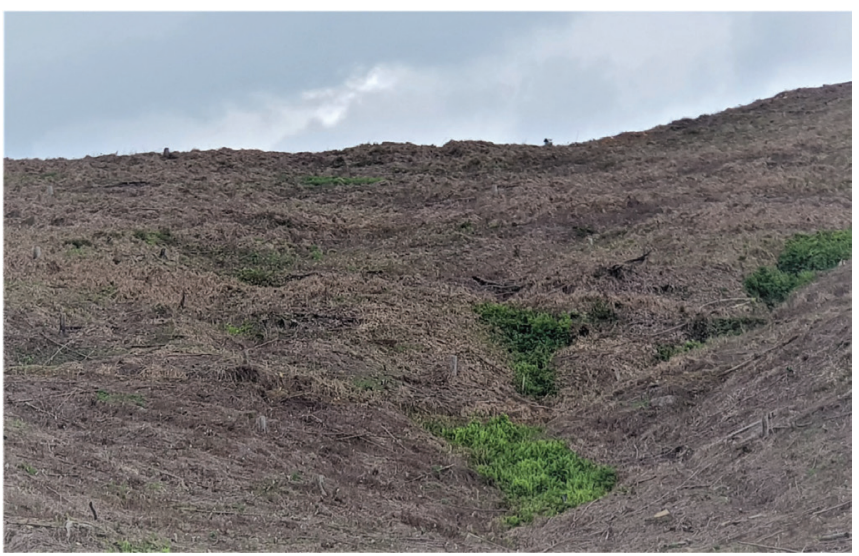

Figure 4 Weed control before planting, showing islands of remnant weed patches

between T1/T2 (manual weed control - mean height $7.1 \mathrm{~m}, \mathrm{DBH} 5.9 \mathrm{~cm}$, SPH 926) and T4 (chemical weed control and fertiliser - mean height $9.5 \mathrm{~m}, \mathrm{DBH} 10.6 \mathrm{~cm}, \mathrm{SPH} 926$ ) were projected to 7 years, and the volume shown in Table 2. These projections indicated the substantial growth difference at clear felling, namely, $203 \mathrm{~m}^{3} \mathrm{ha}^{-1}$ in T4 vs $64 \mathrm{~m}^{3} \mathrm{ha}^{-1}$ in $\mathrm{T} 1 /$ 
Table 2 Projected growth for T1, T2 and T4 treatments at 7 years clear-fell based on 12-month data

\begin{tabular}{|c|c|c|c|c|c|c|c|c|c|c|c|c|}
\hline \multirow{3}{*}{ Treatment } & \multicolumn{3}{|c|}{ Assumptions } & \multicolumn{2}{|c|}{$\begin{array}{c}\text { Total volume } \\
(\%)\end{array}$} & \multicolumn{3}{|c|}{ Volume } & \multicolumn{3}{|c|}{ Value } & \multirow{3}{*}{$\%$} \\
\hline & Age & MAI & Vol@cf & Pulp & Saw & Pulp & Saw & Total & Pulp & Saw & Total & \\
\hline & (yrs) & $\left(\mathrm{m}^{3} \mathrm{ha}^{-1} \mathrm{yr}^{-1}\right)$ & $\left(\mathrm{m}^{3} \mathrm{ha}^{-1}\right)$ & \multicolumn{2}{|c|}{$(\%)$} & \multicolumn{3}{|c|}{$\left(\mathrm{m}^{3}\right)$} & \multicolumn{3}{|c|}{$\left(\mathrm{RM} \mathrm{ha}^{-1}\right)$} & \\
\hline $\mathrm{T} 1, \mathrm{~T} 2$ & 7 & 9.1 & 64 & $92 \%$ & $8 \%$ & 59 & 5 & 64 & 9440 & 1200 & 10640 & 100 \\
\hline $\mathrm{T} 4$ & 7 & 29.0 & 203 & $52 \%$ & $48 \%$ & 106 & 98 & 203 & 16902 & 23403 & 40305 & 379 \\
\hline
\end{tabular}

$\mathrm{MAI}=$ mean annual increment, Vol@cf = volume at clearfell, Pulp = Pulplog, Saw = Sawlog, RM = Malaysian Ringitt

T2. The projected difference in financial return between the two regimes were RM40,305 per ha in T4 vs RM10,640 per ha in T1/T2.

\section{CONGLUSION}

Planted forest establishment benefited from complete weed free silviculture caused by chemical control and intensive management of weeds during early growth (until 12 months), particularly the first six months. Lapses in weed control during early stages of establishment caused reductions in growth that may not be recovered with remedial weed control treatments. The lack of response to both remedial weed control and fertiliser applications confirmed that stands of Acacia mangium may not be cost effectively rehabilitated by later aged weeding or fertiliser application. In this respect, plantation trees differ from crops such as oil palm which may be effectively rehabilitated (Williams and Fairhurst 2003). This trial provided a clear example of the advantages of chemical over manual weed control and estimated productivity changes may be used to evaluate their impact on estate management. It also shows that weed-free establishment is more beneficial that fertiliser if only one operation is conducted. Further trials with other species such as Eucalyptus pellita will provide further data on the impact of weed control. This experiment demonstrated the impact of the lack or insufficient weed control on future productivity, as well as the lack of response to further application of fertilisers, once weed competition has affected productivity.

\section{ACKNOWLEDGEMENTS}

This study was part of the tree and silvicultural improvement programmes of the Borneo Forestry Cooperative (www.borneoforestrycoop. com). The authors would like to thank the management of Sabah Softwoods Berhad for their R\&D support.

\section{REFERENCES}

Balneaves JM \& Christie M. 1988. Long term growth response of radiata pine to herbaceous weed control at establishment. New Zealand Journal of Forestry Research 33: 24-25.

Brawner JT, Jarapudin Y, Lapammu M, Rauf R, Boden D \& Wingfield MJ. 2015. Evaluating the inheritance of Ceratocystis acaciivora symptom expression in a diverse Acacia mangium breeding population. Southern Forests 77: 83-90. doi.org/10.2989/20702620.2015. 1007412

Cellier KM \& Stephens CG. 1980. Effect of fertilizer and weed control on early growth of Pinus radiata in southern Australia. Australian Journal of Forest Research 10: 141-153.

Downes G, Harwood C, Washusen R, Ebdon N, Evans R, White D \& Dumbrell I. 2014. Wood properties of Eucalyptus globulus at three sites in Western Australia: effects of fertiliser and plantation stocking. Australian Forestry 77: 179-188. doi.org/10.1080/00049158.20 14.970742

Ellis RC, Webb DP, Graley AM \& Rout AF. 1985. The effect of weed competition and $\mathrm{N}$ nutrition on the growth of seedlings of Eucalyptus delegatensis in the highland area of Tasmania. Australian Journal of Forest Research 15: 395-408.

Keenan RJ, Parsons M, O'loughlin E et al. 2004. Plantations and Water Use: A Review. FWPRDC Report PN04.4005, Melbourne.

Messina MG. 1990. Herbicides increase growth responses to fertiliser in a 5-year Eucalyptus regnans plantation. New Zealand Journal of Forestry Research 20: 168-175.

NAmbiar EKS \& Zed PG. 1980. Influence of weeds on water potential, nutrient content and growth of young radiata pine. Australian Journal of Forest Research 10: 279-288.

Nasution A, Glen M, Beadle C \& Mohammed C. 2019. Ceratocystis wilt and canker - a disease that compromises the growing of commercial Acaciabased plantations in the tropics. Australian Forestry 82: 80-93. doi.org/10.1080/00049158.2019.1595347.

PILlaI PKC. 2012. Effects of site management practices on growth and wood properties of eucalypts in Kerala. PhD. thesis. Forest Research Institute University, Dehra Dun. 
RICHARDSON R. 1993. Vegetation management practices in plantation forests in Australia and New Zealand. Canadian Journal of Forest Research 23: 1989-2005.

Roux J \& WingFIELD MJ. 2009. Ceratocystis species: emerging pathogens of non-native plantation Eucalyptus and Acacia species. Southern Forests 71: 115-120. doi. org/10.2989/SF.2009.71.2.5.820

SAnds R \& Nambiar EKS. 1984. Water relations of Pinus radiata in competition with weeds. Canadian Journal of Forest Research 14: 233-237.

Sankaran KV, Pillai PKC \& Pandalai RC. 2013. Impact of weeds on productivity of Eucalyptus tereticornis plantations in Kerala. Pp 54-58 in Balu A et al. (eds) Forest Health Management. Institute of Forest Genetics and Tree Breeding, Coimbatore.
Schumann AW. 1989. Weed research. Pp 64-72 in Upfold SJ (ed.) Annual Research Review. Institute for Commercial Forestry Research, Pietermaritzburg, South Africa.

Wagner RG, Little Km, Richardson B \& Mcnabb K. 2006. The role of vegetation management for enhancing productivity of the world's forests. Forestry 79: 57-79. doi:10.1093/forestry/cpi057

WiLKINSON GR \& NeILSON WA. 1990. Effect of herbicides on woody weed control and growth of plantation eucalypt seedlings. Australian Forestry 53: 69-78.

Williams G \& Fairhurst TH. 2003. Implementation of best management practices in an oil palm rehabilitation project. Better Crops International 17: 16-19. 